\title{
Acid Pretreatment of Sago Wastewater for Biohydrogen Production
}

\author{
Noor Illi Mohamad Puad ${ }^{1, *}$, Nurainin Farhan Abd Rahim², and Azlin Suhaida Azmi ${ }^{1}$ \\ ${ }^{1}$ Bioprocess and Molecular Engineering Research Unit, Department of Biotechnology Engineering, \\ Kulliyyah of Engineering, International Islamic University Malaysia, P.O Box 10, 50728 Kuala \\ Lumpur, Malaysia
}

\begin{abstract}
Biohydrogen has been recognized to be one of the future renewable energy sources and has the potential in solving the greenhouse effects. In this study, Enterobacter aerogenes (E. aerogenes) was used as the biohydrogen producer via dark fermentation process using sago wastewater as the substrate. However, pretreatment of sago wastewater is required since it consists of complex sugars that cannot be utilized directly by the bacteria. This study aimed to use acid pretreatment method to produce high amount of glucose from sago wastewater. Three different types of acid: sulfuric acid $\left(\mathrm{H}_{2} \mathrm{SO}_{4}\right)$; hydrochloric acid $(\mathrm{HCl})$ and nitric acid $\left(\mathrm{HNO}_{3}\right)$ were screened for the best acid in producing a maximum amount of glucose. $\mathrm{H}_{2} \mathrm{SO}_{4}$ gave the highest amount of glucose which was $9.406 \mathrm{~g} / \mathrm{L}$. Design of experiment was done using Face-centred Central Composite Design (FCCCD) tool under Response Surface Methodology (RSM) in Design Expert 9 software. The maximum glucose $(9.138 \mathrm{~g} / \mathrm{L})$ was recorded using $1 \mathrm{M} \mathrm{H}_{2} \mathrm{SO}_{4}$ at $100{ }^{\circ} \mathrm{C}$ for $60 \mathrm{~min}$. A batch dark fermentation using $E$. aerogenes was carried out and it was found that pretreated sago wastewater gave a higher hydrogen concentration (1700 $\mathrm{ppm}$ ) compared to the raw wastewater (410 ppm).
\end{abstract}

\section{Introduction}

Hydrogen gas has the potential as a viable alternative fuel and energy carrier of the future since it is a clean fuel with no $\mathrm{CO}_{2}$ emissions and can be used for generation of electricity. Hydrogen has an enthalpy energy of $122 \mathrm{~kJ} / \mathrm{g}$ which is 2.75 times greater than hydrocarbon fuels [1]. Hydrogen can be produced chemically and biologically. Indirect biophotolysis, photofermentation, dark fermentation and hybrid system are the examples of biohydrogen process [2]. Dark fermentation is the production of biohydrogen from microorganisms using agricultural waste as the substrate [3]. E. aerogenes is a facultative anaerobe hydrogen producing bacteria that can alter the oxygen condition to anoxic condition that recovered the activity of $\mathrm{Fe}$-hydrogenase to produce hydrogen via dark fermentation [4].

In this study, sago wastewater was used instead of sago fibrous pith residues as the alternative substrate for source of glucose production since it contains a high amount of starch [5]. It was reported that about $2.2 \mathrm{~mol} \mathrm{H}_{2} / \mathrm{mol}$ glucose was produced by Escherichia

\footnotetext{
* Corresponding author: illi@,iium.edu.my
} 
coli using sago wastewater as a substrate [6] which showed. Since sago wastewater has complex structure sugars, it needs to be broken down into the simpler fermentable sugar to be utilized by E. aerogenes. Two common hydrolysis methods in sago wastewater pretreatment are acid and enzymatic pretreatment. In acid hydrolysis, acid acts as a catalyst that breaks the glycosidic bond into maltose, maltotriose, glucose and dextrin depending on which chain is attacked [7]. In the enzymatic hydrolysis, amylase is used to breakdown the starch into fermentable sugars [8]. However, those reported pretreatments are specifically for sago sago fibrous pith residues and not sago wastewater.

This study was carried out to determine the optimum conditions for the acid pretreatment of sago wastewater in order to obtain maximum fermentable sugar to be used as the substrate by E. aerogenes for biohydrogen production.

\section{Method}

\subsection{Collection, preparation and charaterization of sago wastewater}

Sago wastewater was collected from a sago mill in Batu Pahat, Johor. The sago wastewater was in brownish color with approximately composed of $60 \%$ water and $40 \%$ sediment. Characterization of sago wastewater was conducted using the standard method for examination of wastewater [9]. Upon use, the wastewater was kept in the cold room to prevent the growth of bacteria while its sediment was sun-dried for 9 hours and then blended into the powder form.

\subsection{Screening of acid solution for sago wastewater pretreatment}

Three acid solutions that have been chosen for the screening purpose were $\mathrm{H}_{2} \mathrm{SO}_{4}, \mathrm{HCl}$ and $\mathrm{HNO}_{3}$. The aim of the screening was to select the acid that produced the highest amount of glucose from the sago wastewater. Thus, only type of acid solution was varied, while the value of other parameters which were acid concentration $(0.5 \mathrm{M})$, incubation temperature $\left(90{ }^{\circ} \mathrm{C}\right)$ and incubation time (40 $\left.\mathrm{min}\right)$ were kept constant. Sago wastewater samples were used with the composition of $100 \mathrm{~mL}$ of sago liquid and $2 \mathrm{~g}$ of dried sediment. About 150 $\mathrm{mL}$ of $0.5 \mathrm{M}$ of each acid was added into $250 \mathrm{~mL}$ conical flask and the solution was stirred well for 1-2 minutes on the hotplate magnetic stirrer at the room temperature. The solution was then placed into the water bath at $90{ }^{\circ} \mathrm{C}$ for 40 minutes.

After that, samples were cooled down in the ice water bath and filtered using vacuum filter in order to separate any solid particles from the aqueous solution. $\mathrm{NaOH}(2 \mathrm{M})$ solution was added into the filtered solutions for neutralization. The solution was then submerged in the ice water bath to absorb the heat of neutralization and to avoid further decomposition of fermentable sugars [7]. Lastly, glucose concentration was analyzed using dinitrosalicylic acid (DNS) method [10].

\subsection{Optimization of pretreatment process parameters}

Three parameters of acid pretreatment were chosen to be optimized which are acid concentration $(\mathrm{M})$, incubation temperature $\left({ }^{\circ} \mathrm{C}\right)$ and incubation time $(\mathrm{min})$ with the selected ranges as shown in Table 1 . This selection of ranges was varied respectively based on the previous reports [11-13]. Then, the experiment was designed using FCCCD of RSM in the Design Expert 9 software for the analysis of optimum condition for acid pretreatment of sago wastewater. The response was the concentration of glucose $(\mathrm{g} / \mathrm{L})$ and all experiments were conducted in triplicates. 
Table 1. Experimental range and level of three parameters used in the study.

\begin{tabular}{|c|c|c|c|}
\hline Factor & \multirow{2}{*}{$\begin{array}{c}\text { Incubation temperature } \\
\left({ }^{\circ} \mathbf{C}\right)\end{array}$} & $\begin{array}{c}\text { Incubation time } \\
(\mathbf{m i n})\end{array}$ & $\begin{array}{c}\text { Acid concentration } \\
(\mathbf{M})\end{array}$ \\
\hline 1 & 100 & 90 & 1.5 \\
\hline 0 & 85 & 60 & 1.0 \\
\hline-1 & 70 & 30 & 0.5 \\
\hline
\end{tabular}

\subsection{Fermentation of $E$. aerogenes for biohydrogen production}

\subsubsection{Preparation of E. aerogenes inoculum}

The inoculum was prepared aerobically by adding $10 \mathrm{~mL}$ of E. aerogenes broth in a 250 $\mathrm{mL}$ conical flask with $90 \mathrm{~mL}$ LB media. The flask was placed in an incubator shaker at 180 $\mathrm{rpm}$ and $37^{\circ} \mathrm{C}$ for 18 hours. The bacteria were actively grown at the exponential phase after 4 hours of inoculation and it was then used as the inoculums or stock culture [14]. Then, the OD of the inoculum was measured at the wavelength of $600 \mathrm{~nm}$ using a spectrophotometer.

\subsubsection{Media preparation}

Two different media that contains the pretreated and raw (non-treated) sago wastewater, respectively were prepared. The raw sago wastewater was prepared by mixing $2 \mathrm{~g}$ of sediment with $100 \mathrm{~mL}$ of sago liquid. The pretreated sago wastewater was prepared by mixing $2 \mathrm{~g}$ sediment with $100 \mathrm{~mL}$ sago liquid and the pretreatment process was conducted according to the suggested parameters from the RSM model in the Design Expert 9.0 which were for $88.01 \mathrm{~min}$ at $99.9^{\circ} \mathrm{C}$ using $1.31 \mathrm{M} \mathrm{H}_{2} \mathrm{SO}_{4}$ concentration and it was then followed by filtration and $\mathrm{pH}$ neutralization as mentioned in Section 2.2. The initial glucose concentration for both media were then measured using DNS method.

\subsubsection{Experimental set-up and batch fermentation process}

Serum bottles with a capacity of $125 \mathrm{~mL}$ were used for the dark fermentation of $E$. aerogenes which was air-sealed and covered with a silicon stopper and aluminium seal cap [15]. An amount of $4 \mathrm{~mL}$ inoculum was added to each $76 \mathrm{~mL}$ raw and pretreated sago wastewater to make a final working volume of $80 \mathrm{~mL}$. The fermentation was conducted in duplicates at $37^{\circ} \mathrm{C}$ with $180 \mathrm{rpm}$ for 48 hours [14]. After 48 hours of incubation, the glass syringe was used to collect the hydrogen gas accumulated in the serum bottle and then the hydrogen analysis was performed. The final glucose concentration in each serum bottle was measured using DNS analysis to observe the glucose conversion after acid pretreatment.

\subsubsection{Hydrogen gas analysis}

Hydrogen gas was accumulated in the serum bottle after 48 hours. Hydrogen gas concentration for each sample was analyzed using a portable hydrogen gas analyzer and expressed in the unit of part per millions (ppm). If the concentration was more than 1125 ppm, gas dilution was done by taking $10 \mathrm{~mL}$ of biogas and mixing it in the $125 \mathrm{~mL}$ of empty serum bottle. After that, the concentration of hydrogen was measured again. During gas collection using the glass syringe, the gas pushed up the glass syringe. Thus, the total 
volume of biogas equals to the total volume of gas in the serum bottle $(45 \mathrm{~mL})$ and gas in the glass syringe. The biogas in the serum bottles consist of carbon dioxide, hydrogen, methane and other gases.

\section{Results and Discussions}

\subsection{Screening of acid solution}

It was observed that pretreatment using $\mathrm{H}_{2} \mathrm{SO}_{4}$ produced the highest glucose concentration which was $9.406 \mathrm{~g} / \mathrm{L}$ compared to $\mathrm{HCl}$ and $\mathrm{HNO}_{3}$ (Table 2). This result is in agreement with [16] which reported that $\mathrm{H}_{2} \mathrm{SO}_{4}$ was the best solution for lignocellulosic biomass pretreatment in producing simple sugars. This is due to the ability of diluted $\mathrm{H}_{2} \mathrm{SO}_{4}$ to effectively remove and recover most of the hemicellulose as dissolved sugars. It was also concluded that $\mathrm{H}_{2} \mathrm{SO}_{4}$ reached about $72 \%$ dissolution of polysaccharides compared to $\mathrm{HCl}$ which was only $41 \%$ dissolution [17]. $\mathrm{HNO}_{3}$ has also recorded a good conversion of starch to glucose, but its higher price would result in less cost effective in acid recovery for hydrolysis [11]. Based on these reasons, $\mathrm{H}_{2} \mathrm{SO}_{4}$ was used as the acid solution for optimizing sago wastewater pretreatment parameters.

Table 2. Comparison of glucose concentration after sago wastewater pretreatment using different types of acid at $0.5 \mathrm{M}$.

\begin{tabular}{|c|c|}
\hline $\begin{array}{c}\text { Type of acid } \\
(\mathbf{0 . 5} \mathbf{~ M )}\end{array}$ & Glucose concentration $(\mathbf{g} / \mathbf{L})$ \\
\hline $\mathrm{HCl}$ & 6.902 \\
\hline $\mathrm{H}_{2} \mathrm{SO}_{4}$ & 9.406 \\
\hline $\mathrm{HNO}_{3}$ & 7.615 \\
\hline
\end{tabular}

\subsection{Optimization of process parameters for sago wastewater acid pretreatment}

Based on the experimental design using FCCCD in Design Expert 9.0, a total of 20 runs were carried out for different ranges of incubation temperature $\left(70,80\right.$ and $\left.100{ }^{\circ} \mathrm{C}\right)$, incubation time (30,60 and $90 \mathrm{~min})$ and acid concentration $(0.5,1$ and $1.5 \mathrm{M})$. The initial glucose concentration in the raw sago wastewater was measured and its concentration was less than $0.1 \mathrm{~g} / \mathrm{L}$. Hence, it can be considered that before pretreatment, sago wastewater contained insignificant amount of glucose. Table 3 lists out glucose concentration $(\mathrm{g} / \mathrm{L})$ for all 20 runs that haven conducted. Acid pretreatment at $100{ }^{\circ} \mathrm{C}$ for 60 minutes with $1 \mathrm{M}$ $\mathrm{H}_{2} \mathrm{SO}_{4}$ gave the highest amount of glucose which was $9.138 \mathrm{~g} / \mathrm{L}$ (Run 13).

Further analysis on the glucose concentration using ANOVA was carried out and the result is summarized in Table 4. It shows that the model given was significant since (Prob $>$ F-value $<0.05$ ) and the lack of fit was not significant (Prob $>F$ value $>0.1$ ). In addition, the most significant factor affecting the maximum glucose concentration is the incubation temperature where its value of "Probability $>F$ " was 0.0001 which was less than 0.05 . It was then followed by acid concentration and incubation time which were less significant. This result can be supported by the previous findings which concluded that at the mild temperature $\left(\sim 120^{\circ} \mathrm{C}\right)$, there was a significant recovery of sugar produced while a higher temperature of pretreatment would cause in the sugar degradation and thus lead to the formation of inhibitors [18]. 
Table 3. Glucose concentration in sago wastewater after acid pretreatment as a response during optimization using FCCCD.

\begin{tabular}{|c|c|c|c|c|}
\hline Run & $\begin{array}{c}\text { Incubation } \\
\text { temperature }\left({ }^{\circ} \mathbf{C}\right)\end{array}$ & $\begin{array}{c}\text { Incubation } \\
\text { time (min) }\end{array}$ & $\begin{array}{c}\text { Acid } \\
\text { concentration } \\
(\mathbf{M})\end{array}$ & $\begin{array}{c}\text { Glucose } \\
\text { concentration } \\
(\mathbf{g} / \mathbf{L})\end{array}$ \\
\hline 1 & 85 & 30 & 1 & 2.54 \\
\hline 2 & 85 & 60 & 0.5 & 3.47 \\
\hline 3 & 85 & 60 & 1 & 3.41 \\
\hline 4 & 85 & 60 & 1 & 4.47 \\
\hline 5 & 85 & 60 & 1 & 4.02 \\
\hline 6 & 85 & 60 & 1 & 5.14 \\
\hline 7 & 85 & 60 & 1 & 8.93 \\
\hline 8 & 85 & 60 & 1.5 & 4.68 \\
\hline 9 & 85 & 90 & 1 & 5.84 \\
\hline 10 & 70 & 90 & 0.5 & 0.69 \\
\hline 11 & 100 & 90 & 1.5 & 9.08 \\
\hline 12 & 100 & 90 & 0.5 & 7.00 \\
\hline 13 & 100 & 60 & 1 & 9.13 \\
\hline 14 & 100 & 30 & 0.5 & 4.77 \\
\hline 15 & 100 & 30 & 1.5 & 8.67 \\
\hline 16 & 70 & 30 & 0.5 & 0.48 \\
\hline 17 & 70 & 60 & 1 & 0.33 \\
\hline 18 & 70 & 30 & 1.5 & 1.45 \\
\hline 19 & 70 & 90 & 1.5 & 6.39 \\
\hline 20 & 85 & 60 & 1 & \\
\hline
\end{tabular}

Since incubation temperature is a crucial factor that affects directly to the production of glucose compared to other factors, choosing the appropriate temperature is essential depending on the types of agricultural wastes used in the pretreatment. The "Lack of Fit Fvalue" of 0.37 implies that the lack of fit condition is not significant and it is a $92.17 \%$ chance of the value could occur due to noise. This non-significance lack of fit is good since the model is required to be fitted to the linear regression. The final equation in terms of actual factors is shown in Equation 1.

Glucose concentration $=-18.71970+0.23806 \times$ Incubation temperature $+0.02424 \times$
Incubation time $+1.5592 \times$ Acid concentration

Although the highest glucose amount has been achieved from acid pretreatment of sago wastewater in Run 13 (Table 3), its process parameters have yet to be optimized. This is based on the 3D response surface model shown in Fig. 1. It depicts that a higher temperature $\left(>100^{\circ} \mathrm{C}\right)$ should be used in order to obtain an optimized pretreatment temperature. Monavari et al. (2009) [19] proposed that acid pretreatment should be carried out using $\mathrm{H}_{2} \mathrm{SO}_{4}$ with the concentration range of 0.5 to $1.5 \%(\mathrm{w} / \mathrm{w})$ at the temperature of 121-160 ${ }^{\circ} \mathrm{C}$. From the pretreatment conditions, the yield of sugar from hemicelluloes achieved was $70 \%-95 \%$. 
Table 4. ANOVA Analysis Regression coefficient of predicted models for the response of glucose concentration.

\begin{tabular}{|c|c|c|c|c|c|c|}
\hline Source & $\begin{array}{c}\text { Sum of } \\
\text { square }\end{array}$ & DF & $\begin{array}{c}\text { Mean } \\
\text { square }\end{array}$ & F-value & $\begin{array}{c}\text { Probability> } \\
\text { F }\end{array}$ & \\
\hline Model & 138.88 & 3 & 46.29 & 20.20 & $<0.0001$ & Significant \\
\hline $\begin{array}{c}\text { Incubation } \\
\text { temperature ( }{ }^{\circ} \text { C) }\end{array}$ & 127.51 & 1 & 127.51 & 55.64 & $<0.0001$ & \\
\hline $\begin{array}{c}\text { Incubation time } \\
\text { (min) }\end{array}$ & 5.29 & 1 & 5.29 & 2.31 & 0.1483 & \\
\hline $\begin{array}{c}\text { Acid } \\
\text { concentration } \\
(\mathbf{M})\end{array}$ & 6.08 & 1 & 6.08 & 2.65 & 0.1230 & \\
\hline Residual & 36.67 & 16 & 2.29 & & & \\
\hline $\begin{array}{c}\text { Lack of fit } \\
\text { Pure error }\end{array}$ & 16.44 & 11 & 1.49 & 0.37 & 0.9217 & $\begin{array}{c}\text { Not } \\
\text { significant }\end{array}$ \\
\hline Cor total & 175.55 & 19 & & & & \\
\hline
\end{tabular}

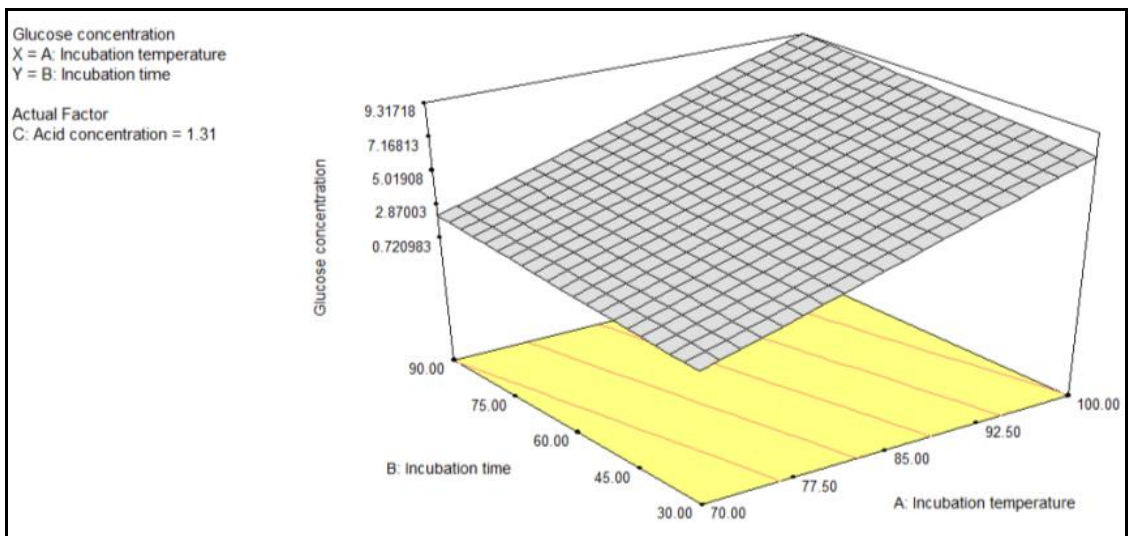

Fig. 1. 3D response surface for model graph.

\subsection{Fermentation of $E$. aerogenes for biohydrogen production using pretreated sago wastewater}

A batch dark fermentation experiment was carried out to examine the feasibility of pretreated sago wastewater as the substrate for biohydrogen production using E. aerogenes. Raw sago wastewater was used as the control. The results shown in Table 5 demonstrates that the pretreated sago wastewater is a potential substrate for E.aerogenes to produce biohydrogen. The final concentration of biohydrogen achieved in the media supplemented with pretreated sago wastewater was $1700 \mathrm{ppm}(3.59 \mu \mathrm{mol})$ which is about 4 times higher compared to the raw sago wastewater. It shows that pretreatment is essential in order to break down the complex sugar into the simplest one so that $E$. aerogenes can easily utilize the sugar to carry out their metabolic activities for biohydrogen production. Previously, it was reported that E. aerogenes produced $1.0 \mathrm{~mol}$ of hydrogen from $1.0 \mathrm{~mol}$ of glucose [20]. 
Table 5. The final concentration of biohydrogen produced by E. aerogenes after 48 hours of incubation.

\begin{tabular}{|c|c|c|}
\hline Substrate & $\begin{array}{c}\text { Final concentration of } \\
\text { hydrogen }(\mathbf{p p m})\end{array}$ & $\begin{array}{c}\text { Concentration } \\
\text { of hydrogen } \\
(\boldsymbol{\mu m o l})\end{array}$ \\
\hline Raw sago wastewater & 410 & 0.81 \\
\hline $\begin{array}{c}\text { Pretreated sago } \\
\text { wastewater }\end{array}$ & 1700 & 3.59 \\
\hline
\end{tabular}

\section{Conclusions}

$\mathrm{H}_{2} \mathrm{SO}_{4}$ was used in the sago wastewater acid pretreatment since the glucose concentration based on its absorbance showed the highest value compared to $\mathrm{HCl}$ and $\mathrm{HNO}_{3}$. The optimization study of pretreatment process parameters for maximum glucose production using FCCCD was yet to achieve due to the range of temperature used but the highest glucose produced $(9.138 \mathrm{~g} / \mathrm{L})$ was achieved from run $13\left(1 \mathrm{M} \mathrm{H}_{2} \mathrm{SO}_{4}\right.$ at $100{ }^{\circ} \mathrm{C}$ for 60 minutes) with a significant model based the ANOVA analysis. For hydrogen analysis after fermentation, the pretreated sago wastewater achieved was about 4 times higher of hydrogen concentration compared to the raw sago wastewater.

Overall, acid pretreatment sago wastewater is an important step before any agricultural waste can be used as the substrate for fermentation in producing biofuel and biohydrogen. Optimization of important pretreatment parameters such as incubation temperature and concentration of acid is important to improve the yield of glucose from the complex sugars.

\section{References}

1. Y. Nalakath, C. M. Malikudy, J. Jose, International Journal of Engineering Research \& Technology 6, (2017)

2. K. Nath, \& Das, D., Journal of Scientific \& Industrial Research 63, (2004)

3. T. A. Ulhiza, N. I. M. Puad, A. S. Azmi, Journal of Advanced Research in Materials Science 38, 21-31 (2017)

4. N. I. M. Puad, N. A. Mamat, A. S. Azmi, International Proceedings of Chemical, Biological \& Environmental Engineering (IPCBEE) 93, 55-61 (2016)

5. K. Sabariswaran, Papitha, P., Selvakumar, S., \& Raj, S. P., Journal of Biodiversity and Environmental Sciences 3, 17-23 (2013)

6. N. I. M. Puad, S. Sulaiman, A. S. Azmi, Y. Shamsudin, M. Mel, Journal of Engineering Science and Technology, 11-21 (2015)

7. E. C. Kumoro, A. C. Ngoh, G. C. Hasan, M. Ong, C. H. Teoh, Asian Journal of Scientific Research 1, 412-420 (2008)

8. R. Sunaryanto, Handayani, B.H., \& Safitri, R., Microbiology Indonesia 7, 68-74 (2013).

9. A. P. H. Association, in Work. Assoc. Environ. Fed. (1998), pp. 552.

10. G. L. Miller, Analytical Chemistry 31, 426-428 (1959)

11. M. Tutt, Kikas, T., \& Olt, J. , Biosystem Engineering Special Issue, 269-276 (2012).

12. K. J. Dussán, Silva, D. D. V, Moraes, E. J. C., Priscila, V., \& Felipe, M. G. A., Chemical Engineering Transactions 38, 433-438 (2014)

13. M. Idrees, A. Adnan, S. Sheikh, F. A. Qureshic, EXCLI Journal 12, 30-40 (2013)

14. P. Mishra, D. Das, International Journal of Hydrogen Energy 39, 7496-7507 (2014)

15. J. Procházka, J. Mrázek, L. Štrosová, K. Fliegerová, J. Zábranská, M. Dohányos, Engineering in Life Sciences 12, 343-351 (2012) 
16. L. P. Ramos, Química Nova 26, 863-871 (2003).

17. S. Koti, S. P. Govumoni, J. Gentela, L. Venkateswar Rao,. SpringerPlus 5, 1545 (2016)

18. B. Yang, C. E. Wyman, Biofuels, Bioproducts and Biorefining 2, 26-40 (2008)

19. S. Monavari, M. Galbe, G. Zacchi, Biotechnology for Biofuels 2, 6 (2009)

20. S. Tanisho, N. Kamiya, N. Wakao, Bioenergetics 973, 1-6 (1989) 